\title{
New distributional records for Chilean bryophyte and lichen flora
}

\section{Nuevos registros de distribución geográfica para la flora briofítica y liquénica de Chile}

\author{
Carolina A. León ${ }^{1 *}$, Gisela Oliván ${ }^{1} \&$ Raquel Pino-Bodas ${ }^{1,2}$ \\ ${ }^{1}$ Departamento de Biología Vegetal I, Facultad de Ciencias Biológicas, Universidad Complutense de Madrid, E-28040 Madrid. \\ ${ }^{2}$ Botanical Museum, Finnish Museum of Natural History, P.O. Box 7, FI-00014 University of Helsinki, Finland. \\ *leon.valdebenito@gmail.com
}

\begin{abstract}
Ten new distributional records to the Chilean bryo-lichenic flora are reported. Three species and a subspecies are new to the flora of the province of Chiloé, five species are new from the Los Lagos Region and one species is new to mainland Chile. The specimens were collected in peatlands (Sphagnum bogs) and swamp forests of Tepualia stipularis in Isla Grande de Chiloé (Chile) $\left(41^{\circ}-43^{\circ} \mathrm{S} ; 74^{\circ}-73^{\circ} \mathrm{W}\right)$. Diagnostic characters, chemistry (only lichens), habitats preferences and distribution are provided. The national ranges of two species are expanded.
\end{abstract}

KeYwords: New records, southern South America, mosses, liverworts, lichens.

\section{RESUMEN}

Se reportan 10 nuevos registros de distribución geográfica para la flora brio-liquénica de Chile. Tres especies y una subespecie son nuevas para la provincia de Chiloé, cinco especies son nuevas para la Región de Los Lagos y una es nueva para Chile continental. Los especímenes fueron recolectados en turberas esfagnosas y bosques anegados de Tepualia stipularis de la Isla Grande de Chiloé (Chile) $\left(41^{\circ}-43^{\circ} \mathrm{S} 74^{\circ}-73^{\circ} \mathrm{W}\right)$. Se proveen caracteres diagnósticos de las especies, química (sólo para líquenes), preferencias de hábitat y distribución. Se extiende el rango de distribución de dos especies.

Palabras clave: Nuevos reportes, sur de Sudamérica, musgos, hepáticas, líquenes.

\section{INTRODUCTION}

Bryological and lichenological knowledge of Chile is still scarce, mainly because large areas have not been visited by botanists yet and there are very few specialists in the country. Normally, cryptogamic plants are not considered in studies of flora and vegetation. Thus, bryophytes and lichens are not included in the Red Book on Chilean Terrestrial Flora (Benoit 1989).

Nonetheless, cryptogamic plants of southern Chile have an interesting floristic value (Rozzi et al. 2008). In Chile, 890 moss taxa (Müller 2009), 553 liverwort taxa (Hässel de Menéndez \& Rubies 2009) and 1415 lichen taxa (Galloway \& Quilhot 1998) are currently accepted and over $50 \%$ of liverwort and moss species are endemic to the temperate rainforests of southern South America (Rozzi et al. 2008). Despite the latest checklists for mosses (Müller 2009), liverworts (Hässel de Menéndez \& Rubies 2009) and lichens (Feuerer 2012, Galloway \& Quilhot 1998), and the recent floristic works (Burgaz \& Raggio 2007, Cuvertino et al. 2012, Frahm 2005, Frey \& Schaumann 2002, Ireland et al. 2010, Ireland et al. 2006, Larraín 2007, Larraín et al. 2010, Larraín \& Vargas 2009, Müller 2009, Villagra et al. 2009), the bryo-lichenic flora of Chile doubtlessly requires more detailed research.

During the fieldwork of floristic and ecological studies in Sphagnum bogs in Isla Grande de Chiloé (Chile) (León 2012), bryophyte and lichen collections were collected to extend the knowledge of cryptogamic vegetation in these ecosystems. Consequently, national, regional and provincial new records are provided, the distributional ranges of two species are expanded, and distinctive characters, chemistry (only lichens), and some notes about similar species are provided. In addition, global and national distributions and habitat preferences are presented. 


\section{MATERIALS AND METHODS}

This study is based on 18 specimens collected in 2009, 2010 and 2011, during field expeditions by the authors.

The study area is situated in the Isla Grande de Chiloé, $\mathrm{X}$ Region-Chile $\left(42^{\circ}-43^{\circ} \mathrm{S}\right.$ and $\left.73^{\circ}-75^{\circ} \mathrm{W}\right)$. The Chiloé climate is wet temperate with strong oceanic influence (Di Castri \& Hajek 1976) and an annual rainfall between 1,900 and 2,300 $\mathrm{mm}$ (CONAF 2009), that reaches 5,000 - 6,000 $\mathrm{mm}$ in some areas (Pérez et al. 2003). The mean summer temperature is $10.2^{\circ} \mathrm{C}$ and the mean winter temperature is $6.2^{\circ} \mathrm{C}$ (Pérez et al. 2003). The material was collected in Ancud, Dalcahue and Chonchi Communes.

Voucher specimens are deposited in MACB and CONC herbaria.

Specimens were carefully determined from morphological characters (macroscopic and microscopic) and their characteristics were compared with descriptions in the literature, type specimens or other herbarium specimens.

For lichens, chemical characters were also studied. The secondary metabolites were identified by thin layer chromatography (TLC) following the protocol of White \& James (1985), using the solvents A, B and C.

\section{RESULTS}

One species (Chiloscyphus breutelii (Gott.) Engel \& Schust.) is new to mainland Chile. Five species are reported for the first time from Los Lagos Region, Pohlia nutans (Hedw.) Lindb., Leptobryum pyriforme (Hedw.) Wilson, Lepidozia fuegiensis Stephani, Cladonia cenotea (Ach.) Schaer. and Cladonia bellidiflora (Ach.) Schaer. Furthermore, three species, Conostomum pentastichum (Brid.) Lindb., Riccardia alcicornis (Hook. f. \& Tayl.) Trev. and Cladonia mitis Sandst. and a subspecies, Cladonia gracilis subsp. elongata (Wulfen) Vain are new to the flora of Chiloé Province.

One asterisk $(*)$ represents species reported as new to the province of Chiloé; two $(* *)$, species new to Los Lagos Region; and three (***) species new to Chile.

\section{Mosses}

BARTRAMIACEAE

*Conostomum pentastichum (Brid.) Lindb., Öfvers. Förh. Kongl. Svenska Vetensk.-Akad. 20: 392. 1863.

CHILE, Región de Los Lagos, Chiloé, Ancud, sector Pumanzano, turbera antropogénica (pomponal),

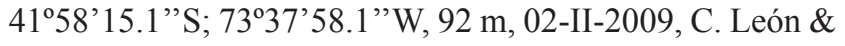
A. Benítez 102972 (MACB).

This circumsubantarctic species has been reported in
West \& South Patagonia, Tierra del Fuego, Falkland Islands, South Georgia Island, Kerguelen, Tasmania, Auckland Islands, Campbell Islands and New Zealand (Seki 1974). In Chile, it is known from Araucanía Region to Magallanes Region (Müller 2009). In Los Lagos Region it was only known from Antillanca locality, Province of Osorno (Deguchi 1991). This is a new record from Chiloé Province.

This species was collected on peatland soil, mixed with Isotachis madida (Hook. f. \& Taylor) Mitt., at the edge of a bog.

C. pentastichum can be easily recognized by leaves clearly 5-ranked; costa excurrent; apical leaf cells thickened and with thick mamillae in the distal angles; capsule subglobose.

DesCription AND ILLUSTRATION: Matteri (1985).

\section{BRYACEAE}

**Leptobryum pyriforme (Hedw.) Wilson, Bryol. Brit. 219. 1855.

CHILE, Región de Los Lagos, Chiloé, Dalcahue, Laguna Los Caulles, turbera de origen glaciar, 42 $2^{\circ} 13$ '25.2"S 73³2'52.9”W, 153 m, 12-IV-2011, C. León, G. Oliván \& A. Benítez 102973 (MACB).

L. pyriforme has a cosmopolitan distribution and it is known from the Coquimbo Region to the Magallanes Region, in 12 localities according to Müller (2009). However, it had not been registered in Los Lagos Region until now, being this the first record.

Specimens were found growing in peatland soil, on peat and remains of campfires.

This species is distinguished by its capsule being clearly pyriform, light brown; setae 0.8 to $3.5 \mathrm{~cm}$ long, reddish; leaves long and narrow, yellow-green and costa percurrent.

Description and illustration: Smith (2004), Ochyra et al. (2008) and Porley (2008).

**Pohlia nutans (Hedw.) Lindb., Musci Scand. 18. 1879.

CHILE, Región de Los Lagos, Chiloé, Ancud, Estación Biológica Senda Darwin, turbera antropogénica (pomponal), 41 $52^{\circ} 47,0^{\prime}$ 'S 7340'07,9”W, 24 m, 30-I-2009, C. León \& A. Benítez 101577 (MACB). sector Lecam, turbera antropogénica, $41^{\circ} 56^{\prime} 22.80^{\prime \prime} \mathrm{S} 73^{\circ} 34^{\prime} 31.75^{\prime \prime} \mathrm{W}, 60 \mathrm{~m}, 31$ I-2009, C. León \& A. Benítez 101578 (MACB).

P. nutans is considered a bipolar species (Seki 1974). In Chile, it has been recorded from the Biobío Region to the Magallanes Region (Müller 2009). However, it had not been registered in Los Lagos Region, being this its first record for the region. 
The plants were found growing on peatland soil, mixed with Sphagnum magellanicum.

According to Shaw (1983) and Suárez (2008), this species is highly variable in size and morphology. Nevertheless, the collected material is distinguished by oval-lanceolate leaves with serrate margin near to the apex, costa percurrent; capsule red-orange with distinct neck; endostome segments broadly perforate along the keels; cilia long; axillary gemmae lacking.

Description and illustration: Shaw (1983) and Suárez (2008).

\section{LiVERWORTS}

\section{LOPHOCOLEACEAE}

***Chiloscyphus breutelii (Gott.) Engel \& Schust., Nova Hedwigia 39: 412. 1984[1985].

CHILE, Región de Los Lagos Chiloé, Chonchi, Parque Nacional Chiloé, bosque de Tepualia stipularis, 42³7'02.9”S 7406'07.3”W, 153 m, 04-IV-2010, C. León, G. Oliván \& A. Benítez 102970 (MACB).

This species is widely distributed in tropical and subtropical areas of South America (Gradstein \& Pinheiro da Costa 2003). In Chile, it was only cited by Fulford (1976) as Lophocolea trapezoides Mont. from the north of the country, although without naming the exact locality. The occurrence in Chile could now be confirmed.

The plants were found growing on forest soil, among other bryophytes.

Distinctive characters include: leaves rectangular or orbicular; scarcely decurrent, margin with 4 to 6 long slender cilia; underleaves connate with both row of leaves, wing narrow or scarcely developed.

Chiloscyphus quadridentata is very similar to $C$. breutelii but has leaves with only 3(-4) cilia (Gradstein \& Pinheiro da Costa 2003).

Description AND ILLustration: Fulford (1976) and Gradstein $\&$ Pinheiro da Costa (2003).

\section{LEPIDOZIACEAE}

**Lepidozia fuegiensis Stephani, Kongl. Svenska Vetensk. Acad. Handl., n.s. 46(9): 63. f. 24: f-g. 1911.

CHILE, Región de Los Lagos, Chiloé, Ancud, Estación Biológica Senda Darwin, bosque de Tepualia stipularis, 4152'47.0”S 7340'07.9”'W, 24 m, 27-III-2010, C. León, G. Oliván \& A. Benítez 102969 (MACB).

Lepidozia fuegiensis is endemic to southern South America. Up to now this species was reported from relict temperate forest of Fray Jorge, located in Coquimbo Region
(Villagrán et al. 2004). Also, it was reported from Aysén to Magallanes Region (Hässel de Menéndez \& Rubies 2009). Thus, an extensive distributional gap between the Mediterranean and Valdivian ecoregion was observed. This is the first record for Los Lagos Region and the occurrence in the Valdivian rainforest ecoregion can now be confirmed.

The specimen was collected on forest soil, among other bryophytes.

The most important diagnostic characters are: small plants, $0.5-1.5 \mathrm{~cm}$ wide, bipinnate; leaves subquadrate to rectangular, segments in conspicuous pairs, incurved, triangular from 2 to 6 cells.

Description and illustration: Fulford (1966) and Engel (1978).

\section{Aneuraceae}

*Riccardia alcicornis (Hook. f. \& Tayl.) Trev., Mem. Reale Ist. Lombardo Sci., Ser. 3, Cl. Sci. Mat. 4: 431. 1877.

CHILE, Región de Los Lagos, Chiloé, Ancud, desembocadura Río Chepu, turbera antropogénica (pomponal); 42 03'10.8"S 73059'56.8”'W, 5 m, 29-III2010, C. León, G. Oliván \& A. Benítez 102971 (MACB).

R. alcicornis is endemic to southern South America. In Chile, it has been registered in Valdivian, Nordpatagonic and Subantarctic ecoregions (Villagrán et al. 2005), from 10 Provinces. In Los Lagos Region is only known from two Provinces, Osorno and Llanquihue (Hässel de Menéndez $\&$ Rubies 2009). This is the first report from Province of Chiloé.

Specimens were found growing on peatland soil, mixed together with Sphagnum magellanicum

This species is distinguished by its filamentous thallus, pinnate or bipinnate, wide 1 to 2.5 times the thickness; small cells with thickened walls and dorsal papillae.

Description And illustration: Hässel de Menéndez (1972)

\section{LICHENS}

\section{Cladoniaceae}

**Cladonia bellidiflora (Ach.) Schaer., Lich. Helv. Spicil. 1(1): 21. 1823.

CHILE, Región de Los Lagos, Chiloé, Ancud, Estación Biológica Senda Darwin, turbera antropogénica (pomponal), 4152'47.0"S 7340’07.9” W, 27-III-2010, G. Oliván, C. León, \& A. Benítez 102965 (MACB). Dalcahue, Laguna Los Caulles, turbera de origen glaciar, 42 13 '25.2"S 73³2'52.9”W, 153 m, 12-IV-2011, G. Oliván, C. León \& A. Benítez 102966 (MACB).

This species has a bipolar distribution (Burgaz \& Raggio 
2007). In Chile, the species has been registered only in Aysén and Magallanes Regions, in four Provinces (Stenroos 1995). This is the first report from Los Lagos. Thus, this record extends the northern distributional range of the species in Chile.

The specimens were found growing on rotting wood and peat, at the edge of a bog.

This species is very variable, but it can be distinguished from others species by the red hymenial discs; simple to slightly branched podetia; surface of podetia discontinuously corticate and densely squamulose.

Description AND illustration: Stenroos \& Ahti (1990), Stenroos et al. (1992) and Stenroos (1995).

Chemistry: $\mathrm{P}+$ yellow or red, $\mathrm{K}-\mathrm{o} \mathrm{K}+$ yellow, $\mathrm{C}$-; thamnolic acid. Four chemotypes were reported from Magallanes Region: I) fumarprotocetraric acid complex; II) fumarprotocetraric acid complex and usnic acid; III) usnic, thamnolic and fumarprotocetraric acid complex; IV) thamnolic acid (Burgaz \& Raggio 2007). The Chiloé collections contain the chemotype IV.

**Cladonia cenotea (Ach.) Schaer., Lich. Helv. Spicil. 1(1): 35.1823.

CHILE, Región de Los Lagos, Chiloé, Dalcahue, Laguna Los Caulles, turbera de origen glaciar; $42^{\circ} 13$ '25.2"S 73³2'52.9”'W, 153 m, 12-IV-2011, G. Oliván, C. León, \& A. Benítez 102968 (MACB).

C. cenotea has a bipolar distribution (Stenroos \& Ahti 1990). It has been recorded in Chile only in Magallanes, Tierra del Fuego and Antártica Chilena Provinces (Stenroos 1995). This is the first record for Los Lagos region and Chiloé. This record extends its northern distribution range in Chile. The distributional gap that occurs between Chiloé and Magallanes could be explained by the few bryological collections made in Aysén Region.

Specimens were found growing in peatland soil, on oxidized peat.

It is distinguished by its simple or sparsely branched podetia, apices always open forming scyphoid structures and podetial surface with farinose soredia.

Description And illustration: Stenroos \& Ahti (1990), Stenroos et al. (1992) and Stenroos (1995).

Chemistry: P- o P + yellow, K- or K + yellow, C-; thamnolic acid. There is other chemotype containing squamatic acid that is the commonest in northern hemisphere, in Europe and North America (Burgaz \& Ahti 2009, Hammer 1995, James 2009, Piercey-Normore 2006). Nevertheless, thamnolic acid is more common in South America (Stenroos et al.
1992). The material of Chiloé contains thamnolic acid, as in Tierra del Fuego.

*Cladonia gracilis subsp. elongata (Wulfen) Vain, Acta Soc. Fauna Flora Fenn. 53(1): 92. 1922.

CHILE, Región de Los Lagos, Chiloé, Ancud, Estación Biológica Senda Darwin, turbera antropogénica (pomponal), 4152'47.0"S 7340'07.9”W, 24 m, 30-I-2009, C. León \& A. Benítez 102961 (MACB). Desembocadura Río Chepu, turbera antropogénica (pomponal), $42^{\circ} 03^{\prime} 10.8^{\prime \prime} \mathrm{S}$ 7359'56.8”W, 5 m, 29-III-2010, C. León, G. Oliván \& A. Benítez 102958 (MACB). Sector Pumanzano, turbera antropogénica (pomponal), 41 ${ }^{\circ} 58^{\prime} 15.1$ 'S $73^{\circ} 37^{\prime} 58.1$ 'W, 92 m, 02-II-2009, C. León \& A. Benítez 102963 (MACB). Dalcahue, Predio Municipal Teguel, turbera antropogénica

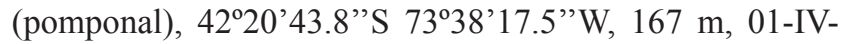
2010, C. León, G. Oliván \& A. Benítez 102959 (MACB). Chonchi, Sector Púlpito, turbera de origen glaciar, 4245'24.6”S 73²4’06.6”W, 110 m, 03-II-2009, C. León \& A. Benítez 102960 (MACB), 03-IV-2010, C. León, G. Oliván \& A. Benítez 102962 (MACB).

Cladonia gracilis subsp. elongata is a taxon with bipolar distribution (Stenroos et al. 1992). In Chile, it has been recorded from Los Lagos Region to Magallanes. In addition, it has been found in the Juan Fernández Archipelago (Stenroos 1995). In Los Lagos Region, it is only known from Osorno Province. This is the first record for Chiloé Province.

Specimens were found growing in peatland soil, on oxidized peat.

It is distinguished by podetia simple to slightly branched, subulate or with narrow scyphi, with marginal proliferations.

Description and illustration: Stenroos \& Ahti (1990), Stenroos et al. (1992) and Stenroos (1995).

Chemistry: P + red, K- o K + yellow, C-; fumarprotocetraric acid complex and atranorin. The magellanic material contains fumarprotocetraric acid complex, quaesitic acid and atranorin (rare) (Burgaz \& Raggio 2007). While in Chiloé material quaesitic acid is lacking.

*Cladonia mitis Sandst., Sandstede: Clad. Exs. 55. 1918.

CHILE, Región de Los Lagos, Chiloé, Dalcahue, Predio Municipal Teguel, turbera antropogénica (pomponal), $42^{\circ} 20^{\prime} 43.8^{\prime \prime} \mathrm{S} 73^{\circ} 38^{\prime} 17.5^{\prime}$ W, 167 m, 01-IV-2010, C. León, G. Oliván \& A. Benítez 102964 (MACB). Ancud, sector Cogomó junto al Río Negro, turbera de origen glaciar, 41 58'31.5”S 7343'58.5”W, 15 m, 01-II-2009, C. León \& A. Benítez 102967 (MACB).

C. mitis is considered a bipolar species. In Chile, this 
species has been recorded from Biobío to Magallanes Region. In Los Lagos Region it is known only from two Provinces, Osorno and Llanquihue (Stenroos 1995). This is the first record from the Province of Chiloé.

The specimen was found growing in peatland soil, on Sphagnum magellanicum.

Distinctive characters of the species include: podetia whitish, richly branched, branching anisotomic, mainly trichotomous and tetrachotomous.

Description and illustration: Stenroos et al. (1992) and Stenroos (1995).

Chemistry: P-, K-, C-; usnic acid. The Fuegian material (Stenroos et al. 1992) and specimens from Isla Navarino (Burgaz \& Raggio 2007) contain usnic, rangiformic, norrangiformic and isousnic acids. Nevertheless, a chemotype containing only the usnic acid was found in Chiloé. C. mitis is very similar to $C$. arbuscula, but fumarprotocetraric acid complex is lacking (Stenroos et al. 1992) and chemical tests are necessary for an accurate determination.

\section{CONCLUSION}

The biodiversity of peatlands has erroneously been considered uniform and uninteresting. Our floristic and ecological studies in Sphagnum bogs in Chiloé have provided ten new records for Chilean bryolichenic flora. Most species reported in this research are bipolar or cosmopolitan. Nevertheless, two of the species studied are endemic of temperate rainforest of southern South America and two of the species reported extend their known distribution range northwards.

Our contribution highlights the importance of peatlands for flora conservation, and the need to improve the knowledge of bryolichenic flora of these ecosystems in Chile in order to create conservation policies.

\section{ACKNOWLEDGEMENTS}

This research was supported by AECID A/025081/2009, Cooperación al Desarrollo UCM 4138114 and AECID A/030011/2011 grants. We are very grateful to Alfonso Benítez-Mora for his field assistance. We thank Elena Araujo for her help with TLC. C. A. León acknowledges the support from a doctoral fellowship provided by CONICYTGobierno de Chile. We also thank Reinaldo Vargas y Juan Larraín for their comments and suggestions on the manuscript.

This is a contribution to the Research Program of LTSER-Chile network at Senda Darwin Biological Station, Chiloé, Chile.

\section{BIBLIOGRAPHY}

Benoit, I. 1989. Libro rojo de la flora terrestre de Chile. Santiago, Chile: Corporación Nacional Forestal. Impresora Creces Ltd. 157 pp.

Burgaz, A. R. \& T. Анті. 2009. Cladoniaceae. Madrid: Sociedad Española de Liquenología. 111 pp.

Burgaz, A. R. \& J. Raggio. 2007. The Cladoniaceae in the Navarino Island (Prov. Antártica Chilena, Chile). Mycotaxon 99: 103-116.

CONAF. 2009. Plan de Acción Provincial Chiloé - Plan de Gestión Territorial. Oficina Provincial Chiloé - Corporación Nacional Forestal. 49 pp.

Cuvertino, J., V. Ardiles, F. Osorio \& X. Romero. 2012. New records and additions to the Chilean bryophyte flora. Ciencia e Investigación Agraria 39(2): 245-254.

Deguchi, H. 1991. A list of moss collections made during the Expeditions to Chile in 1981 and 1987 (1). Bulletin of the National Science Museum, Tokyo, Series B, Botany 17 (1): $15-34$

Di Castri, F. \& E. R. HajeK. 1976. Bioclimatología de Chile. Santiago, Chile: Editorial Universidad Católica de Chile. $128 \mathrm{pp}$.

ENGEL, J. J. 1978. A taxonomic and phytogeographic study of Brunswick Peninsula (Strait of Magellan) Hepaticae and Anthocerotae Fieldiana: Botany 41(i-viii): 1-319.

Feuerer, T. 2012. Checklist of lichens and lichenicolous fungi of Chile. http://www.biologie.uni-hamburg.de/checklists/ south-america/chile_1.htm. Viewed: January 12, 2012.

Frahm, J. P. 2005. A contribution to the Campylopus flora of Chile. Tropical Bryology 26: 39-43.

Frey, W. \& F. Schaumann. 2002. Records of rare southern South American bryophytes - Studies in austral temperate rain forest bryophytes 18. Nova Hedwigia 74(3-4): 533-543.

Fulford, M. H. 1966. Manual of the leafy Hepaticae of Latin America Part II. Memoirs of the New York Botanical Garden 11: 173-276.

Fulford, M. H. 1976. Manual of the leafy Hepaticae of Latin America Part IV. Memoirs of the New York Botanical Garden 11: 393-535.

Galloway, D. J. \& W. Quilhot. 1998. Checklist of Chilean lichenforming and lichenicolous fungi. Gayana Botánica 55: 111-185.

Gradstein, S. R. \& D. Pinheiro da Costa, 2003. The Hepaticae and Anthocerotae of Brazil. Memoirs of the New York Botanical Garden 87: 1-318.

Hammer, S. 1995. A synopsis of the genus Cladonia in the northwestern United States. Bryologist 98: 1-28.

Hässel de MenéndeZ, G. 1972. Revisión taxonómica del género Riccardia (especies andinopatagónicas y subantarcticas incluyendo las Islas Juan Fernández, Malvinas y Georgias del Sur). Revista Museo Argentino de Ciencias Naturales "Bernardino Rivadavia" 4(1): 1-242.

Hässel de Menéndez, G. \& M. Rubies. 2009. Catalogue of the Marchantiophyta and Anthocerotophyta from Chile, Argentina and Uruguay. Nova Hedwigia 134: 1-672.

Ireland, R., G. Bellolio, J. Larraín \& R. Rodríguez. 2010. Studies on the moss flora of the Bío-Bío Region of Chile: Part 2. Tropical Bryology 32: 39-44.

Ireland, R., G. Bellolio, R. Rodríguez \& J. Larraín. 2006. 
Studies on the moss flora of the Bío-Bío Region of Chile. Tropical Bryology 28: 63-77.

James, P.W. 2009. Cladonia. In: C.W. Smith, A. Aptroot, B.J. Coppins, A. Flechter, O.L. Gilbert, P.W. James \& P.A. Wolseley (eds.), The Lichens of Great Britain and Ireland, 309-338. British Lichen Society, London.

Larraín, J. 2007. Adiciones a la flora de musgos de la Isla Grande de Chiloé, Chile. Gayana Botánica 64: 7-23.

Larraín, J., G. SuÁrez, H. Bednarek-Ochyra \& R. Ochyra. 2010. The rediscovery of Dicranella circinata (Dicranellaceae, Bryophyta), with comments on other southern South American species of Dicranella. Nova Hedwigia 91: 361376.

Larraín, J. \& R. Vargas. 2009. New Records for the Chilean Altiplano Cryptogamic Flora. Gayana Botánica 66: 107110.

LEÓN, C.A. 2012. Caracterización florística y ecológica de turberas esfagnosas de la isla Grande de Chiloé-Chile: una herramienta para la conservación y el desarrollo sostenible. Tesis Doctoral. Departamento de Biología Vegetal I, Universidad Complutense de Madrid. 223 pp.

Matteri, C.M. 1985. Bryophyta, Musci: Bartramiaceae. En: S.A. Guarrera, I. Gamundi de Amos \& D. Rabinovich de Halperin (eds.), Flora Criptogámica de Tierra del Fuego 14(7), 62 pp. 18 láminas.

Müller, F. 2009. New records and new synonyms for the Chilean moss flora. Tropical Bryology 30: 76-83.

Müller, F. 2009. An updated checklist of the mosses of Chile. Archive for Bryology 58: 1-124.

Ochyra, R., R.I. Lewis Smith \& H. Bednarek-Ochyra. 2008. The Illustrated Moss Flora of Antarctica. Cambridge University Press. 685 pp.

Pérez, C. A., J.J. Armesto, C. Torrealba \& M.R. Carmona. 2003. Litterfall dynamics and nitrogen use efficiency in two evergreen temperate rainforests of southern Chile. Austral Ecology 28(6): 591-600.

Piercey-Normore, M.D. 2006. Lichen from the Hudson Bay Lowlands: diversity in the southeastern peatlands of Wapusk National Park, Manitoba. Canadian Journal of Botany 84: 1791-1793.

Porley, R. 2008. Arable Bryophytes: Field Guide: The Mosses, Liverworts and Hornworts of Cultivated Land in Britain and Ireland. Wild Guides Ltd. $140 \mathrm{pp}$.

Rozzi, R., J.J. Armesto, B. Goffinet, W. Buck, F. Massardo, J. Silander, M.T.K. Arroyo, S. Russell, C.B. Anderson, L.A. Cavieres \& J.B. Callicott. 2008. Changing lenses to assess biodiversity: patterns of species richness in subAntarctic plants and implications for global conservation. Frontiers in Ecology and the Environment 6(3): 131-137.

SEKI, T. 1974. A moss flora of Provincia de Aisén, Chile. Journal of Science of the Hiroshima University, Series B, Div. 2 (Botany) 15: 9-101.

Shaw, A.J. 1983. Phylogeny and ecology of Pohlia Hedw. with a revision of the species of North and Central America. Dissertation. University of Michigan. $281 \mathrm{pp}$.

Sмith, A.J.E. 2004. The moss flora of Britain and Ireland. Cambridge, UK: Cambridge University Press. 1012 pp.

Stenroos, S. 1995. Cladoniaceae (Lecanorales, lichenized Ascomycotina) in the flora of Chile. Gayana Botánica 52 (2): 89-131.

Stenroos, S. 2002. Key for the identification of the Cladoniaceae of Chile. http://www.biologie.uni-hamburg.de/checklists/ lichens/south-america/chile k.htm\#key. Viewed: 1 September 2009.

Stenroos, S. \& T. Ahti. 1990. The lichen family Cladoniaceae in Tierra del Fuego: problematic or otherwise noteworthy taxa. Annales Botanici Fennici 27: 317-327.

Stenroos, S., L. Ferraro \& T. Ahti. 1992. Cladoniaceae. En: S.A. Guarrera, I. Gamundí de Amos \& D. Rabinovich de Halperin (eds.), Flora Criptogámica de Tierra del Fuego, 1-111. Consejo Nacional de Investigaciones Científicas y Técnicas de la República Argentina, Buenos Aires.

SuÁrez, G. 2008. Sistemática y Filogenia de las Especies Neotropicales del Género Pohlia (Musci). Tesis Doctoral. Universidad Nacional de Tucumán. 268 pp.

Villagra, J., D. Montenegro, C. San Martín, C. Ramírez \& I. Álvarez. 2009. Estudio de la flora liquénica de las turberas de la Comuna de Tortel (Región de Aisén), Patagonia chilena. Anales del Instituto de la Patagonia 37 (1): 53-62.

Villagrán, C., J.J. Armesto, L.F. Hinojosa, J. Cuvertino, C. Pérez \& C. Medina. 2004. El enigmático origen del bosque relicto de Fray Jorge. En: F.A. Squeo, J.R. Gutiérrez \& I.R. Hernández (eds.), Historia Natural del Parque Nacional Fray Jorge, 3-43. Ediciones Universidad de La Serena, La Serena.

Villagrán, C., G. Hässel de Menéndez \& E. Barrera. 2005. Hepáticas y Anthocerotes del Archipiélago de Chiloé. Santiago de Chile: Corporación de Amigos del Museo Nacional de Historia Natural. 160 pp.

White, J. \& P. W. James. 1985. A new guide to microchemical techniques for the identification of lichen substances. Bulletin of the British Lichen Society 57: 1-41.

Recibido: 26.12 .12

Aceptado: 30.04 .13 